\title{
Aikuiskasvatuksen Tutkimusseura (ATS) tiedottaa
}

\section{OSALLISTU 2019}

\section{Tiedejulkaisemisen päivät}

Aika ja paikka: 8.-9. lokakuuta, Tieteiden talo, Helsinki

Teema: "Avoimuus, vastuullisuus ja kieli"

Lisätiedot: tiedejulki.fi

\section{Mimer-verkoston konferenssi}

Aika ja paikka: 5.-6. marraskuuta, Linköping

University, Linköping

Lähetä paperisi työkonferenssiin viimeistään 4.10.2019, annika.pastuhov @liu.se

Lisätiedot: old.liu.se/mimer?|=sv

\section{ETMU Days}

Aika ja paikka: 14.-15. marraskuuta, Tampereen yliopisto, Tampere

Teema: "Solidarity, participation and politics"

Pääpuhujat: Dr. Prem Kumar Rajaram (Central European University, Itävalta), Dr. Elisa Pascucci (Helsingin yliopisto) ja Dr. Nira Yuval-Davis (University of East London, Yhdistynyt kuningaskunta)

Lisätiedot: events.tuni.fi/etmu2019

\section{Kasvatustieteen päivät}

Aika ja paikka: 21.-22. marraskuuta, Itä-Suomen yliopisto, Joensuu

Teema: "Oppimisen maisemat muuntuvat - entäpä sitten?"

Pääpuhujat: Senior Lecturer Lucila Carvalho (Institute of Education, Massey University Uusi-Seelanti) ja Kasvatustieteen professori Minna Huotilainen (Helsingin yliopisto)

Lisätiedot: uef.fi/web/kt-paivat2019

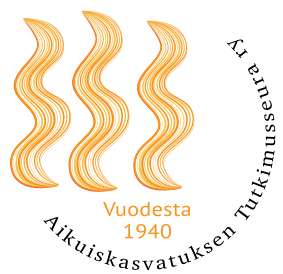

OSALLISTU 2020

\section{Aikuiskasvatuksen tutkimuspäivät}

Aika ja paikka: 13.-14. helmikuuta, Lapin yliopisto, Rovaniemi

Teema: "Elämän kestävä vastuu"

Lisätiedot: aikuiskasvatuksentutkimusseura.fi/tutkimuspaivat

\section{NERA 2020}

Aika ja paikka: 4.-6. maaliskuuta, Turun yliopisto, Turku

Teema: Rethinking the futures of education in the Nordic countries

Pääpuhujat: Professor Fazal Rizvi (University of Melbourne), Professor Kirsti Klette (University of Oslo), Professor Risto Rinne (University of Turku) Lähetä abstrakti viimeistään 15. marraskuuta. Lisätiedot: https://nera2020.fi

\section{LIITY JÄSENEKSI}

Tiedeseuran jäseneksi voi liittyä jokainen aikuiskasvatuksesta kiinnostunut, alalla toimiva tai tutkimusseuran toiminnasta kiinnostunut henkilö tai yhteisö.

Lisätiedot: aikuiskasvatuksentutkimusseura.fi/jasenyys

\section{OSALLISTU KESKUSTELUUN SOMESSA}

verkkosivuilla: aikuiskasvatuksentutkimusseura.fi/ tutkimuspaivat

Facebookissa: facebook.com/aikuiskasvatuksentutkimusseura

Twitterissä: twitter.com/aikuiskasvatus 